Discussion

Papers

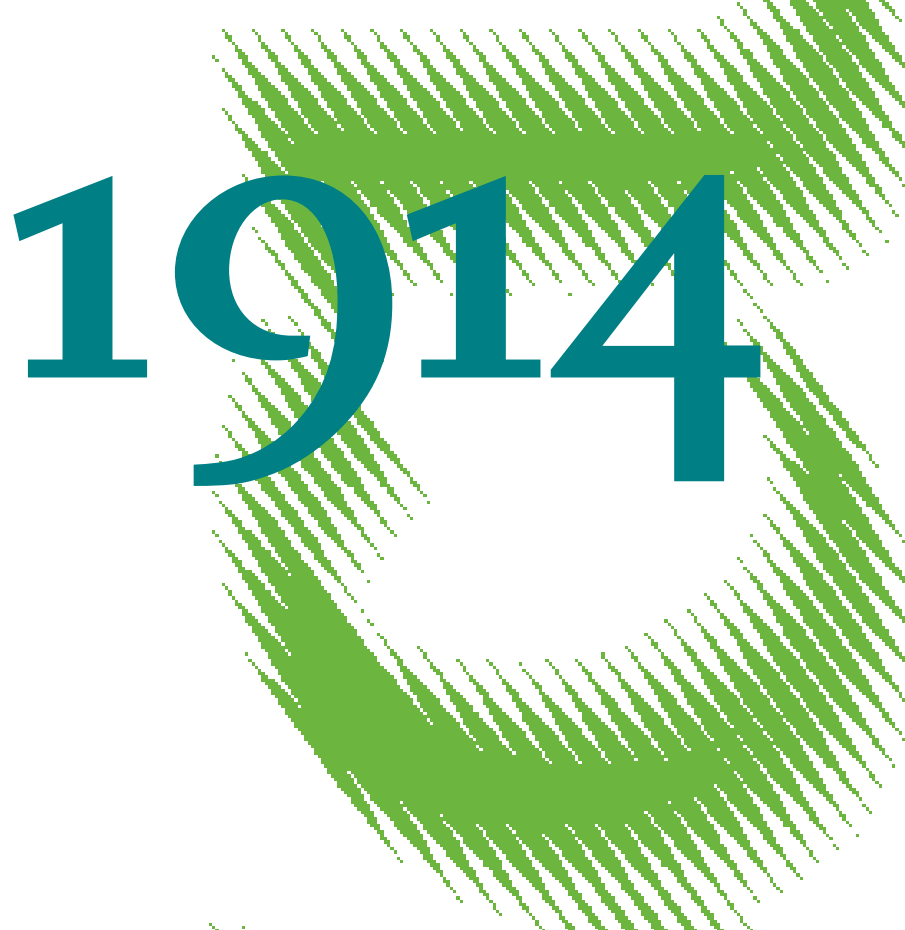

The Relationship between Financial Literacy and Financial Inclusion 
Opinions expressed in this paper are those of the author(s) and do not necessarily reflect views of the institute.

IMPRESSUM

(C) DIW Berlin, 2020

DIW Berlin

German Institute for Economic Research

Mohrenstr. 58

10117 Berlin

Tel. +49 (30) $89789-0$

Fax +49 (30) $89789-200$

http://www.diw.de

ISSN electronic edition 1619-4535

Papers can be downloaded free of charge from the DIW Berlin website:

http://www.diw.de/discussionpapers

Discussion Papers of DIW Berlin are indexed in RePEc and SSRN:

http://ideas.repec.org/s/diw/diwwpp.html

http://www.ssrn.com/link/DIW-Berlin-German-Inst-Econ-Res.html 


\title{
The Relationship between Financial Literacy and Financial Inclusion
}

\author{
Antonia Grohmann and Lukas Menkhoff
}

\begin{abstract}
About two billion people in the world do not own a financial account and there are many more who use financial services only occasionally. In the past, initiatives which address these problems of financial exclusion focused on the supply side of financial markets, in particular by increasing the branch network of banks and by offering cheap bank products. While this had the desired effect, recent evidence shows that improving the demand side of financial markets is also helpful. There are numerous initiatives and public policies to enhance financial education and to improve financial literacy. Microeconometric studies, often randomized controlled trials, show that financial literacy has a causal effect on financial inclusion; educated individuals understand the advantages of financial services better but also feel more confident about contacting providers. Cross-country evidence indicates that in poorer countries improved financial supply and demand are substitutes, i.e., they work independently of each other. In higher-income economies, however, these instruments are complements, i.e., it is useful to improve financial literacy in order to make better use of available financial services.
\end{abstract}

Keywords: Financial inclusion; financial literacy; financial development

JEL codes: G 53 (financial literacy); O 16 (financial markets)

November 2020

We thank Brenda Cude, Gianni Nicolini and Helke Seitz for helpful comments.

Antonia Grohmann, Aarhus University, Department of Economics and Business Economics, Fuglesangs Allé 4, 8210 Aarhus V, Denmark, and DIW Berlin, agrohmann@ diw.de.

Lukas Menkhoff, DIW Berlin,10108 Berlin, Germany, and Humboldt-Universität zu Berlin, lmenkhoff@diw.de. 
Financial education has many objectives. While improvement in financial literacy may have a value in itself, as education in general does, financial education is usually seen as a tool to reach further objectives. These objectives differ depending on perspective, but in each case financial education can improve financial literacy, contribute to better financial decisions, and in the end improve welfare (Kaiser \& Menkhoff, 2017; Lusardi \& Mitchell, 2014). One of the objectives of financial education is to ease access to formal financial services. If individuals use formal financial services, they are regarded as being financially included. While this objective seems to be less problematic in many advanced economies, world-wide there are almost two billion people who do not have access to any financial accounts, and thus are financially excluded at this most basic level (Demirgüç-Kunt et al., 2018).

It is obvious that there are certain groups which do not have (full) access to financial services, and these groups tend to have less financial literacy (Klapper \& Lusardi, 2020); financial education will arguably support their financial inclusion. In advanced economies, financial exclusion refers to groups with low socio-economic status who have problems to properly manage their financial affairs. This may mean that people do not save for retirement or do not have access to loans at traditional banks. In developing economies, financial inclusion is often even more basic by aiming to improve access to formal financial services for large parts of the population. Here, the simplest empirical measure of financial inclusion is whether a person owns any kind of a formal financial account. However, financial inclusion is not really reached if someone just owns an account, as the account should also be actively used, and even better, it should be used in a rational way. Using these more comprehensive definitions of financial inclusion, the shortcomings in financial inclusion are even more severe. These measures can be applied to all countries in the world.

In the past, initiatives to improve financial inclusion mainly addressed the supply side of financial markets, in particular by improving the branch network of banks. This often was approached by starting community banks with lower access barriers and by offering products targeted to low-income people. The products typically are cheaper and easier to understand than standard bank products. While this approach has some desired effects, additional barriers remain as not even free bank accounts are fully used (Dupas et al., 2018). Among these barriers are (usually) high fees, long distances to travel to bank branches as well as demand side barriers in financial markets that result in potential customers deciding not to use financial services. Such refusals to use financial services can be reduced by improving financial literacy, so that 
these individuals better understand the advantages of financial services but also feel more confident to contact providers.

In order to provide an overview of related issues, this chapter is arranged as follows. In Section 2 we will introduce the objectives of financial inclusion, its measures, and its status in the world economy. Section 3 discusses determinants, from the supply-side as well as the demand side, that are known to influence the degree of financial inclusion. Section 4 discusses evidence of how financial literacy can contribute to improve financial inclusion, while Section 5 concludes the chapter.

\section{Financial inclusion: Objectives, measures and status}

\subsection{The objectives of financial inclusion}

The World Bank is a major proponent of financial inclusion, and even "made it a key priority to promote financial inclusion" according to leading World Bank authors Demirgüç-Kunt et al. (2020, p.S2). The foundation of this prioritization of financial inclusion is based on research findings that show that access and use of formal financial services can have growth and welfare improving effects (Barajas et al., 2020). These findings are strongest for the effect of payment services and bank account ownership according to Demirgüç-Kunt et al. (2017) in their overview of the link between financial inclusion and inclusive growth. Financial inclusion can be seen as the finance-related objective equivalent to the modified growth concepts of pro-poor growth, shared growth, and finally inclusive growth, the latter being the preferred World Bank terminology since 2009. Thus financial development should not just promote overall growth, but also have a focus on the weaker parts of society and make sure they also benefit from inclusive financial development.

While the World Bank is definitely the leading international organization regarding "finance and development," it seems noteworthy that the G20 group also supports financial inclusion and financial literacy. The G20 recognized financial inclusion as one of the main pillars of global development at the 2010 meeting in Seoul (see recently, Buch, 2017). Following this, the platform of Global Partnership for Financial Inclusion (GPFI) was founded with its task of implementing the G20 action plan to increase financial inclusion (GFPI, 2020). Also, the current UN agenda of 17 sustainable development goals (SDGs) mentions financial inclusion in the explanations of several of these goals, even though it is not one of the 17 goals explicitly (see, for example, UNSGSA, 2018). Finally, the OECD promotes financial education and 
financial inclusion, among other goals, by organizing the International Network on Financial Education (INFE) (OECD, 2020).

Despite this broad support, the objective of financial inclusion is not without criticism. Without going into detail, the thrust of this critique is related to the critique of financial development in general. It goes back to the fundamental question of whether financial development has an impact on overall development, usually proxied by GDP growth per capita. It seems fair to say that research concludes the answer to this question with a clear and conditional yes (Levine, 1997). Financial development tends to have a positive impact, but not always. There are cases where general development drives financial development (Demetriades \& Hussein, 1996). There may be regions and times where financial development does not lead to growth in certain regulatory environments (De Gregorio \& Guidotti, 1995). There may be more generally a phenomenon of too much finance (Arcand et al., 2015) and, of course, there is limited impact, and no general transformative function of microfinance (Banerjee et al., 2015). Still, there remain enough successful cases so that the average effect is positive.

This finding can be cautiously transferred to the less-researched field of financial inclusion. We do not share the position criticizing "financialization" in general, as, for example, Mader (2017) does because we do not see an alternative to a functioning financial sector in modern capitalist economies. However, we acknowledge potentially negative effects of policies pushing individuals into formal financial markets; this can lead to overindebtedness and suboptimal decisions due to a lack of understanding (Schicks, 2014). One measure to reduce such problems, although not the only one, is improving financial literacy as we will argue later.

\subsection{Measuring financial inclusion}

Policy evaluation needs empirical measures in order to assess whether policies succeed. In the case of financial inclusion, the established standard measure is that an adult owns an account at a formal financial institution. The definition of an account is usually generous and is not restricted to a current account but also considers in particular savings accounts, which are very common in developing countries. The definition of a formal financial institution means that the institution complies with the nation's banking regulations. In reality, this definition may be less clear than it sounds because there is often a continuum of financial institutions serving the public. In particular, the distinction between formal and semi-formal financial institutions can be sometimes debated. For example, there are specialized financial institutions which are less 
regulated or with softer standards in exchange for restricted business activities - these may be counted as formal (because they are regulated) or semi-formal (because they do meet the standard regulatory level). In the end, the authorities (typically the central banks) decide which institution is considered a formal financial institution.

While the resulting so-called "account ownership" rate, i.e., the share of the adult population which owns an account, still dominates the debate, it is clear that ownership is not enough. Of course, ownership is important, especially if it is costly (and even opening an account is costly in a strict sense), but there are two further levels of financial inclusion beyond the basic one. The second, intermediate level of financial inclusion is the active use of an account. The third, advanced level means that financial services are used in a rational way.

Regarding the first and second level, the World Bank provides some measures. For the first level, it collects data to measure the proportion of people over the age of 15 that hold an account (Demirgüç-Kunt et al., 2020). The definition of account used is very broad. For the second level, a good example is whether there is any money deposited in a savings account or if a current account was used for transactions during the last year. Obviously, these definitions of "use" are quite generous and have to be seen as lower bound. They make sense in developing countries where access to banks is relatively difficult. For advanced economies, we have moved toward the third level of financial inclusion; i.e., considering a rational use of financial services. One such measure is whether people invest in a rational way, so that they receive returns that are in line with the amount of risk taken. Furthermore, people borrowing at high interest rates, when lower rates are available, is a measure of sub-optimal financial behavior.

\subsection{The status of financial inclusion in the world economy}

In 2011, the World Bank created a database on financial inclusion in the world economy, the so-called "Global Findex database" (Demirgüç-Kunt et al., 2020). The database covers about 140 countries in the world. For each country, there is information about roughly 1,000 individuals who form a representative sample of the adult population. The survey was updated as a repeated cross-section in 2014 and 2017. Thus, we use the latest available information representing the year 2017. Financial literacy was measured globally in 2014 by including four questions into the survey. This survey is referred to as the Standard and Poor Global Financial Literacy Survey (see Klapper \& Lusardi, 2020, for description). 
Figure 1 shows the degree of financial inclusion in the world by documenting the share of the "banked" population, i.e., the share of adults who own a formal bank account (of any kind), for about 140 countries. Darker colors show a higher degree of financial inclusion. Without any further calculations, the expected can be seen: the degree of financial inclusion varies a lot around the world and financial inclusion is positively related to the income level of the respective economy. The level of financial inclusion is at $69 \%$ of the world's population having an account. Moreover, there is great disparity in this which is of concern for policy makers.

$<$ Figure 1 about here $>$

In particular, low and middle-income countries have below-average degrees of bank account ownership. While this share is above $90 \%$ of the adult population in high-income countries, it is lower otherwise, going down to $34 \%$ in low-income economies (see Figure 1, Panel A). This pattern applies to all areas in the world as Panel B of Figure 2 shows. Leaving aside the highincome economies in all areas of the world, no area comes close to a $60 \%$ account ownership share.

$<$ Figure 2 about here $>$

As many indicators of development are positively correlated with each other, it is no surprise that financial literacy and financial inclusion are positively related to each other. The plot in Figure 3 is based on financial inclusion and financial literacy measured in 2014 on a country level. It shows that there is still a large degree of variation around this generally positive relationship. As a relationship does not indicate causation, and in order to learn more about the determinants of financial inclusion, we discuss the respective literature in the next section.

$<$ Figure 3 about here $>$

\section{Determinants of financial inclusion}

Knowing the determinants of financial inclusion is a necessary condition to formulate policy. There is some research in this area, however, far less research than about financial development. Of course, both objectives, i.e., financial development and financial inclusion, are positively related to each other. However, there is also an important difference as with growth relative to inclusive growth: progress in financial development will tentatively also support the lessincluded segments of society but this is not guaranteed. It would be only an accidental effect if the aim is not to improve the financial situation of the less included rather than the average. 
An influential paper by Beck et al. (2007a) does indeed find that the positive impact of financial development on income is stronger in the lower segments of the income distribution than on average. While this supports a positive role of general financial development, it does not show that financial inclusion can be realized as an automatic byproduct. Lower-income segments are definitely less financially included but these two things are not the same. Thus, even if general financial development is helpful, what could be done more specifically? To answer this question, what do we know about determinants of financial inclusion? We discuss such determinants from the supply- and the demand-side of financial markets, often by relying on the Global Findex database introduced above.

\subsection{Supply side factors}

Acknowledging that financial development has a tentatively positive influence on financial inclusion, we here examine drivers of financial development. The most prominent measure of financial development is private credit, i.e., loans extended by the financial sectors to private borrowers (deliberately neglecting politically-motivated loans to the public sector). A number of measures can be taken to expand private credit. Most basically, there not only needs to be an infrastructure to provide credit, but also the necessary freedom to decide whom to lend to and under which conditions. Moreover, a framework is needed to ensure the reliability and enforcement of loan contracts. While these determinants of financial development are expected to also support financial inclusion, development and inclusion are not the same (Beck et al, 2007b), and there is not much systematic empirical work in this direction.

Beck et al. (2008) study price and non-price barriers to access and use of banking services in developing countries using survey data from 209 banks in 62 countries. They find that such barriers are negatively related to measures of access to finance or financial inclusion. Barriers that are shown to be particularly restrictive are minimum balances for checking accounts, annual fees, and documents required to open an account. The paper further set out to examine the relationship between these barriers and the countries' regulatory framework. They find strong correlations with different measures of bank restrictions, bank disclosure practices, and media freedom.

Following on from this, Beck et al. (2009) named a number of policies that could be pursued to increase access to finance for a broad part of the population. In developing countries, they argue that establishing credit information systems can have positive effects on access to finance, 
especially on access to credit. Similarly, procedures to recover on debt contracts can make a relatively easy contribution to increase access. Encouraging openness and competition can foster access to parts of the population that were previously underserved (see also Barajas et al., 2020). The evidence, on direct state intervention, on the other hand, is more mixed. A concrete suggestion in this respect by Barajas et al. (2020) is to provide government payments via bank accounts.

The most comprehensive paper analyzing supply-side factors of financial inclusion is Allen et al. (2016). They apply the first version of the Findex database from 2011, using 123 countries with about 1,000 randomly surveyed participants each (i.e. dropping about 20 countries because of missing information), and show relationships between a set of supply-side variables and financial inclusion. The latter is measured in three ways, i.e., as account ownership, saving during the last 12 months, and withdrawing money from any account at least three times during a typical month.

Supply-side determinants are available at the country-level. There are three groups of determinants significantly related to financial inclusion, while controlling for individual characteristics: (i) financial inclusion is positively correlated with a lower cost of financial services, such as the costs of opening a bank account or costs of direct credit, (ii) Financial inclusion is linked to better physical infrastructure such as bank and ATM penetration, and (iii) financial inclusion is linked to a more reliable politico-economic environment, such as established legal rights and lower political risks. By contrast, there are other variables with no or little relation to financial inclusion such as deposit insurance, the degree of consumer protection, and ownership of financial institutions by the government or foreign banks (see Allen et al., 2016).

One way to potentially overcome the still high degree of financial exclusion is the use of new financial technology, in particular the use of mobile money (see Demirgüç-Kunt et al., 2018). The idea is that almost all adults, even in poor countries, own a mobile phone, although not necessarily a smart phone, and that financial services can be implemented via these phones. There are indeed success stories in this direction. Starting less than 15 years ago in Kenya, today mobile money has hundreds of millions of customers, and many of them are using formal financial services for the first time, so that financial inclusion has much increased (Suri, 2017).

While mobile money can provide many benefits for its users (see also Aron, 2018), best researched are money transfers in case of adverse shocks. However, there are also limitations. Hamdan et al. (2020) show in a case study of rural Uganda that there is a large gap between 
account owners and mobile money users, as more than 40 percent of mobile money account owners do not actively use the account. Moreover, owners of mobile money accounts reach new segments of the population, but some groups still remain underserved, among them women, older people, and generally those who are less well-off. There also are still gaps in providing mobile money, in particular in remote areas which are underdeveloped in other ways. Finally, many users seem to have problems understanding fees and thus their demand for financial services may be based on "misinterpreted" prices. Overall, financial technology can definitely help to address financial inclusion but may leave out important segments of the population.

\subsection{Demand side factors}

The demand side factors in financial markets relevant to address financial inclusion are made up of smaller customers, not larger firms, and the behavior of these customers depends on their characteristics. Again, Allen et al. (2016) provide the most comprehensive analysis and rely on the data introduced above. In their analysis of the relationship between individual characteristics and financial inclusion, the influence of country characteristics is controlled by using country fixed effects.

Allen et al. (2016) report three regression analyses, one for each measure of financial inclusion (account ownership, financial inclusion, frequency of use), which show quite consistent patterns. Four variables stand out in all of the regressions; they are highly significantly related to financial inclusion. A higher degree of financial inclusion is related to (i) higher income, (ii) better education, (iii) a smaller household size, and (iv) being part of the active workforce (not being unemployed or out of the workforce).

Beyond these strongest relations, other factors may also play a role: women are less likely to be financially included than men but this is only significant for the third measure (frequency of account use). However, this result captures the marginal contribution of gender; women are also less educated than men, earn less etc., so the total effect of gender likely is much larger. The situation is similar for rural areas which are less included, but also characterized by lower incomes and less education. The correlation between financial inclusion and being married is positive, possibly reflecting a settled social situation relative to those who live with children but without a partner. Finally, the relationship of age is less straightforward as it is generally positively related to financial inclusion (going along with earning income and accumulating 
wealth) but the quadratic term has a negative sign, showing a non-linear relationship, meaning that the positive effect of additional years is weaker for older ages.

What is missing in Allen et al. (2016) is a consideration of the influence of financial literacy, which is expected to be positively related to financial inclusion. The question is whether financial literacy has a positive marginal contribution beyond the effect of education, income, and being in the workforce. This has not been examined so far to the best of our knowledge.

\section{The contribution of financial literacy toward financial inclusion}

\subsection{Micro studies}

Klapper and Lusardi (2020) show descriptive evidence that there is a link between financial literacy and financial inclusion. Using the Global S\&P Financial Literacy Survey they show that non-account owners have lower financial literacy levels than account owners. However, this describes a relationship and does not say much about potential causality.

A link between financial literacy and financial inclusion has mostly been studied in individual micro settings. These studies mostly conduct randomized controlled trials (RCTs) during which a treatment group is usually given some sort of training that is designed to increase financial literacy. These RCTs have the advantage that causality is clear and that the effect of financial education on financial behavior can be established without bias. On the other hand, other questions are raised by these RCTs. First, in order to clearly establish the relationship between financial literacy and financial inclusion, any financial education program has to increase financial literacy. Following this, the question arises as to what is the most effective form of financial education. Third, as with most RCTs, the issues regarding external validity come up. It is not clear that a financial literacy program that works in one setting will also work in a different setting.

Given these general issues, we discuss in the following section some relevant RCT-studies. Possibly the earliest one is Cole et al. (2011) who try to answer the question whether low demand for formal financial services is determined by high fixed costs, low financial literacy, or both. In order to answer this question, the authors conduct a large survey in India and in Indonesia. They measure financial literacy using four questions and find levels of financial literacy below those found in most developed countries. 
Financial literacy levels measured in the survey is a clear predictor of demand for three different financial services. These services are commitment savings products, which require customers to save a certain amount or until a certain date to be able to withdraw funding. Financial literacy further predicts interest in deposit collection services and interest in retirement savings products. The survey further suggests that price levels are a determining factor for demand for financial services.

As regressions on the link between financial literacy and financial services demand suffer from unobserved variable bias, Cole et al. (2011) conduct an RCT that aims to increase financial literacy and measure changes in financial behavior. They run an experiment in which participants are either given a short financial literacy training or a subsidy to open an account. The financial literacy training is brief (two hours). Orthogonal to this participants are given different levels of subsidies to open an account ranging in amount from $2 \$$ to $14 \$$ for one account. In this study, subsidies have larger effects on the take-up of bank accounts than the financial literacy training on average. The financial literacy training does, however, have positive effects on bank account take up for the least educated and for those with low levels of financial literacy.

Two things have to be kept in mind when examining these results: First, bank account take up in this study is very low. Only about $10 \%$ of all participants open a bank account. Second, the financial literacy training is very short and it is not clear if financial literacy levels were improved through this training.

Cole et al.'s (2011) study suggests that short trainings that try to pass on key financial concepts only may not be effective in improving financial inclusion and financial decision making. To test this, Carpena et al. (2018) perform an experiment during which participants take part in a financial literacy training that involves five weekly sessions of two or three hours each. Participants are given one of three treatments in addition to the standard financial literacy training. In the first treatment, participants receive a financial incentive to answer financial literacy questions correctly. As part of the second treatment, participants are prompted to set a savings goal and a time frame to reach this goal. In the third treatment, participants are given individual counseling along with the financial literacy training. There also is a pure control group.

The results show that those who participate in any form of financial literacy training are far more likely to hold savings in a formal account. Participants in the goal setting intervention are $8 \%$ more likely to be saving in a bank account compared to the control group (which do not get 
any training), while those in the personalized counseling treatment group are $13 \%$ more likely to save in a formal account compared to the control group. There are two possible reasons for the strong effect of counseling. First, counselors actually help to open the account. Second, participants lack trust in formal financial institutions, which the counselor is able to mitigate.

One reason why many people may not use formal financial services is that they are physically unable to reach a bank. Calderone et al. (2018) study the effect of a financial education program that targets people who have experience with doorstep or franchise banking, an action by a bank to reach groups that cannot go to a bank. The training takes two days and uses different forms of media as teaching methods. In addition, there are also savings reminders in the form of text messages.

The results show that the financial literacy training does increase financial literacy and increases savings one year after the training. The increase comes mostly from an increase in savings at a formal bank and to a lesser extent from an increase in savings at the branchless bank.

A natural question that arises when considering many of the studies mentioned here is whether access to a savings account and increased levels of financial literacy act as substitutes or complements for each other. Do people save more when they are given access to a savings account and financial literacy training together, compared to if they are provided with only one? Jamieson et al. (2014) try to answer that question. They run an RCT in 240 youth clubs in Uganda. One treatment group receives financial literacy training (10 sessions at the youth club). A second treatment arm receives a free savings account for each club (not for each individual). A third treatment group receives both training and a free account. There also is a pure control group.

Jamieson et al. (2014) conclude that financial literacy training increases savings. Their conclusion applies to both formal savings in the provided account and to total savings, as measured by an endline survey. The authors report that financial education increases financial literacy, whereas account ownership does not.

Horn et al. (2020) follow up on the same individuals with another endline survey conducted about five years after the initial survey and treatments. They find that the increase in savings due to any of the treatments is persistent but that the increase in financial knowledge disappears over time. Thus, financial education as well as eased access to savings accounts both lead to desired outcomes. Looking at the point estimates of explaining the change in a savings index, 
there is an order of magnitude increasing from "account only" via "education only" to "account and education." However, the differences are not statistically significant.

A similarly designed study is conducted by Abarcar et al. (2020) with transnational households in the Philippines. Remittances to family members left in the home country can have a number of beneficial effects. However, the process of transferring money can be difficult for migrant workers and family members left behind. The paper studies the effect of an RCT performed with family members in the home country who are given a bank account or a one-day financial literacy training or both.

The study finds that financial education leads to less use of credit and a shift from formal to informal credit. There also is a change in savings behavior. Abarcar et al. (2020), however, find no significant effect of receiving both financial education and a bank account. Take up of the bank account is not affected by financial education and vice versa.

When aiming to improve financial literacy on a large scale and so to improve financial inclusion in a population, introducing financial education at school seems like the obvious choice. Bruhn et al. (2016) study the effect of a large-scale intervention in 892 schools in six states in Brazil. Financial education was introduced into the standard school curriculum and involved classroom training as well as take home exercises. The study analyzes data collected during three interview rounds, as well as administrative data and detailed interviews with teachers.

Bruhm et al. (2016) find that the financial education program increases students' financial proficiency and also has a positive effect on financial knowledge and behaviors of parents of children in the treatment schools. The research also shows improvements in short-term financial behaviors such as savings and money management. However, the authors observe some negative effects in real life purchasing decisions; for example, as use of expensive credit increases.

Ideally, financial education in schools will have not only short-term effects on students, but also will improve their financial behaviors after they have left school. Frisancho (2020) evaluates the effect of an RCT in schools in Peru. Here financial education is introduced in grades nine to eleven in 300 public high schools. Frisancho has access to a detailed survey as well as administrative data from students, teachers, and parents.

Frisancho's (2020) research demonstrates that the program is successful in increasing the students' financial knowledge six months after the intervention. It does not have an effect on the students' propensity to open a bank account in the short run. Three years after the 
intervention, the treatment students are less likely to have problematic credit scores than students who did not receive financial education. Parents of the treatment students transition away from more expensive forms of credit. The teachers' financial knowledge increases about twice as much as the financial knowledge of students, and six months after the treatment the teachers are more likely to save and to save at formal financial institutions.

On the whole these studies show that financial literacy training can be effective in improving financial inclusions. However, as mentioned above, there are concerns of external validity - it is not clear if financial literacy improves financial inclusion in all settings.

\subsection{Cross-country studies}

While there are several case studies showing that financial literacy contributes to financial inclusion, there is, to the best of our knowledge, only one study analyzing this relationship for many countries in a single approach. Grohmann et al. (2018) provide a country-level analysis for 119 to 143 countries, depending on specification and the respective data availability (a less technical presentation of the main results is given in Grohmann \& Menkhoff, 2018). The research shows the influence of supply- and demand-side factors on financial inclusion. In particular, the researchers are interested in testing a potential impact of financial literacy on financial inclusion, while controlling for potentially rivalling factors.

The financial inclusion measure are comprised of the basic measure of account ownership, plus having a debit card and two measures of use - i.e., the proportion of adults who saved and the proportion who used their debit card in the last 12 months. To explain these measures of financial inclusion, the study applies four groups of variables - i.e., (i) information about financial infrastructure representing the supply side of financial markets, specifically financial depth and bank branch penetration, (ii) general country characteristics such as GDP per capita and educational level, (iii) institutional characteristics with relevance for finance, such as the strength of the legal rights index, and finally (iv) a measure of financial literacy.

The measure of financial literacy is based on five survey items. Data are collected by the S\&P Global Financial Literacy survey, using the same representative sample in 2014 that produces the second Findex database. The survey items cover questions about four concepts - i.e., risk diversification, inflation, interest rate, and interest compounding - and thus represent a standard format for eliciting the degree of financial literacy (see Lusardi \& Mitchell, 2014). The item on risk diversification is simplified compared to applications in advanced economies, probably to 
reflect the wider coverage of countries. Moreover, a second item on interest rates is added in an adapted form from Cole et al. (2011). Thus, there are five items in total. The score is condensed into a binary financial literacy score (Klapper et al., 2015) of " 1 " (financially literate) if more than three questions are answered correctly. The score for each country is the proportion of respondents that score a " 1. ."

Stepwise regressions are performed, starting with a simple Ordinary Least Squares (OLS) regression explaining the share of account ownership in a country by the degree of financial literacy. The coefficient is 1.44 and highly significant. Expanding the set of explanatory variables by general country characteristics reduces the coefficient of interest to 0.71 . Considering variables of financial infrastructure and further institutional country characteristics reduces the coefficient explaining the share of account ownership in a country further to 0.51 . Importantly, the consideration of correlated variables reduces the coefficient for financial literacy, but it also increases the R-squared and the coefficient for financial literacy always remains highly significant. Both indicators of financial infrastructure (financial depth and bank branch penetration) remain significant, suggesting that both demand and supply in financial services contribute to increasing financial inclusion. Finally, when interpreting the coefficient, it is clear that the economic impact of higher financial literacy on account ownership is meaningful because, other things equal, a one percentage point increase in the proportion of financially literate people in a country increases the share of account ownership among the population by 0.51 percentage points. This main result holds when analyzing other measures of financial inclusion; i.e. holding a debit card and use of financial products.

In another specification, an interaction term is added to the regression in order to see how financial literacy and financial depth influence each other. Interestingly, the marginal effect of financial literacy on the proportion of the population with a bank account is higher in countries with lower financial depth (such as less credit volume per capita). The interaction term is not significant when the dependent variable is having a debit card. In contrast, the marginal effect of financial literacy on savings and using a debit card is greater in countries with more financial depth. Thus, the positive effect of financial literacy on account ownership works well in countries with lower levels of financial depth, indicating that financial literacy and financial infrastructure act as substitutes. In countries with more financial development (more financial depth), however, financial literacy strengthens the effect of financial infrastructure; i.e., both work as complements. Overall, financial literacy is useful but its role changes from a substitute to a complement when a country's financial infrastructure improves. 
A methodological concern regarding these regressions is the implicitly assumed causal impact of the explanatory variables on financial inclusion. While this may be plausible, one can also think about reverse causality. It is known that financial behavior such as having and using financial accounts contributes to one's financial literacy. Therefore, future research on these issues should aim to apply experimental approaches in micro studies and natural experiments or instrumental variables (IV) estimations in macro studies. Grohmann et al. (2018) test various instruments, all of which support the main finding.

\section{Conclusions}

In this chapter, we examine the relationship between financial literacy and financial inclusion. Financial inclusion can be seen as having three different levels. In its most basic form, it means access to or holding a basic account or a savings account. At the next level, it means use of financial services; i.e., did the person transfer money to or withdraw from the account? At the third level, financial literacy involves rational use of financial services. The definition of financial inclusion is mostly an issue for people living in more developed countries.

Financial inclusion can be seen as the more inclusive and far-reaching extension of financial development. Like financial development, it has a number of positive benefits, such as increased growth and lower rates of inequality within a country. It is therefore a desirable policy goal from an individual as well as from a macroeconomic perspective. Unsurprisingly, financial inclusion is a key policy goal for the World Bank as well as other international institutions.

Most literature so far has focused on supply-side factors that may determine financial inclusion, such as bank branch penetration. Many of these studies have shown that even when access is easy and accounts are relatively cheap, there is still not full take up of simple financial services.

It is therefore important to look at factors that may influence the demand for financial services. One such factor is financial literacy. We here examine microeconomic evidence as well as one cross-country study. Evidence from micro studies is mostly based on randomized controlled trails during which some sort of financial literacy training takes place. Although, not all trials find a significant effect of financial education on financial literacy, the general evidence shows a positive relationship between financial education and financial inclusion. Further evidence on the positive effect of financial literacy on financial inclusion comes from the only (to the best of our knowledge) cross-country study on financial literacy and financial inclusion. Here, there is a clear and positive relationship between financial literacy and financial inclusion. 
Regressions using instrumental variables suggest that the relationship is causal and running from financial literacy to financial inclusion. 


\section{References}

Abarcar, P., Barua, R., \& Yang, D. (2020). Financial education and financial access for transnational households: Field experimental evidence from the Philippines. Economic Development and Cultural Change, forthcoming.

Allen, F., Demirgüç-Kunt, A., Klapper, L. F., \& Martinez Peria, M. S. (2016). The foundations of financial inclusion: Understanding ownership and use of formal accounts. Journal of Financial Intermediation, 27, 1-30.

Arcand, J. L., Berkes, E., \& Panizza, U. (2015). Too much finance? Journal of Economic Growth, 20(2), 105-148.

Aron, J. (2018). Mobile money and the economy: A review of the evidence. World Bank Research Observer, 33(2), 135-188.

Banerjee, A., Karlan, D., \& Zinman, J. (2015). Six randomized evaluations of microcredit: Introduction and further steps. American Economic Journal: Applied Economics, 7(1), 121.

Barajas, A., Beck, T., Belhaj, M., \& Naceur, S. B. (2020). Financial inclusion: What have we learned so far? What do we have to learn? IMF Working Paper 20/157.

Beck, T., Demirgüç-Kunt, A., \& Levine, R. (2007a). Finance, inequality and the poor. Journal of Economic Growth, 12(1), 27-49.

Beck, T., Demirgüç-Kunt, A., \& Martinez Peria, M. S. (2007b). Reaching out: Access to and use of banking services across countries. Journal of Financial Economics, 85(1), 234266.

Beck, T., Demirgüç-Kunt, A., \& Martinez Peria, M. S. (2008). Banking services for everyone? Barriers to bank access and use around the world. The World Bank Economic Review, 22(3), 397-430.

Beck, T., Demirgüç-Kunt, A., Honohan, P. (2009). Access to financial service: Measurement, impact, policy. World Bank Research Observer, 24(1), 119-145.

Buch, C. M. (2017). Financial literacy and financial inclusion: Priorities of the G20 German presidency. Paper for the $4^{\text {th }}$ OECD/GFLEC Global policy research symposium to advance financial literacy.

Bruhn, M., de Souza Leão, L., Legovini, A., Marchetti, R., \& Zia, B. (2016). The impact of high school financial education: Evidence from a large-scale evaluation in Brazil. American Economic Journal: Applied Economics, 8(4), 256-295.

Calderone, M., Fiala, N., Mulaj, F., Sadhu, S., \& Sarr, L. (2018). Financial education and savings behavior: Evidence from a randomized experiment among low-income clients of branchless banking in India. Economic Development and Cultural Change, 66(4), 793825 .

Carpena, F., Cole, S., Shapiro, J., \& Zia, B. (2019). The ABCs of financial education: Experimental evidence on attitudes, behavior, and cognitive biases. Management Science, 65(1), 346-369.

Cole, S., Sampson, T., \& Zia, B. (2011). Price or knowledge: What drives demand for financial services in emerging markets. Journal of Finance, 66(6), 1933-1967.

De Gregorio, J., \& Guidotti, P. E. (1995). Financial development and economic growth. World Development, 23(3), 433-438. 
Demetriades, P. O., \& Hussein, K. A. (1996). Does financial development cause economic growth? Time-series evidence from 16 countries. Journal of Development Economics, $51(2), 387-411$.

Demirgüç-Kunt, A., Klapper, L. F., \& Singer, D. (2013). Financial inclusion and legal discrimination against women: Evidence from developing countries, World Bank Policy Research Working Paper 6416.

Demirgüç-Kunt, A., Klapper, L. F., \& Singer, D. (2017). Financial inclusion and inclusive growth, World Bank Research Working Paper 8040.

Demirgüç-Kunt, A., Klapper, L. F., Singer, D., Ansar, S., \& Hess, J. (2018). The Global Findex Database 2017: Measuring financial inclusion and the fintech revolution. The World Bank.

Demirgüç-Kunt, A., Klapper, L. F., Singer, D., Ansar, S., \& Hess, J. (2020). The Global Findex Database 2017: Measuring financial inclusion and opportunities to expand access to and use of financial services. World Bank Economic Review, 34, S2-S8.

Dupas, P., Karlan, D., Robinson, J., \& Ubfal, D. (2018). Banking the unbanked? Evidence from three countries. American Economic Journal: Applied Economics, 10(2), 257-297.

Frisancho, V. (2020). Is school based financial education effective? Short and long term impacts on students, parents, and teachers. Mimeo.

GPFI (Global Platform for Financial Inclusion) (2020). About GPFI. https://www.gpfi.org/about-gpfi.

Grohmann, A., Klühs, T., \& Menkhoff, L. (2018). Does financial literacy improve financial inclusion? Cross country evidence. World Development, 111, 84-96.

Grohmann, A., \& Menkhoff, L. (2018). Financial literacy promotes financial inclusion in both poor and rich countries. DIW Economic Bulletin, 7 (41), 399-407.

Hamdan, J. S., Lehmann-Uschner, K., \& Menkhoff, L. (2020). Mobile money, financial inclusion and unmet aspirations: Evidence from Uganda. Mimeo.

Horn, S., Jamison, J. Karlan, D., \& Zinman, J. (2020). Does lasting behavior change require knowledge change? Evidence from savings interventions for young adults, NBER Working Paper 28011.

Jamieson, J. C., Karlan, D., \& Zinman, J. (2014). Financial education and savings accounts: Complements or substitutes: Evidence from Ugandan youth clubs, NBER Working Paper 20135.

Kaiser, T., \& Menkhoff, L. (2017). Does financial education impact financial literacy and financial behavior, and if so, when? World Bank Economic Review, 31(3), 611-630.

Klapper, L., Lusardi, A., \& van Oudheusden, P. (2015). Financial literacy around the world: Insights from the Standards and Poor's Ratings Service Global Financial Literacy Survey. https://www.finlit.mhfi.com.

Klapper, L., \& Lusardi, A. (2020). Financial literacy and financial resilience: Evidence from around the world. Financial Management, 49(3), 589-614.

Levine, R. (1997). Financial development and economic growth: Views and agenda. Journal of Economic Literature, 25, 688-726.

Lusardi, A., \& Mitchell, O. S. (2014). The economic importance of financial literacy: Theory and evidence. Journal of Economic Literature, 52(1), 5-44.

Mader, P. (2017). Contesting financial inclusion. Development and Change, 49(2), 461-483. 
OECD (Organization for Economic Co-operation and Development) (2020). OECD International Network on Financial Education. https://www.oecd.org/financial/education/oecd-international-network-on-financialeducation.htm.

Ozili, P. K. (2020). Financial inclusion research around the world: A review. Forum for Social Economics, forthcoming.

Schicks, J. (2014). Over-indebtedness in microfinance - An empirical analysis of related factors on the borrower level. World Development, 54, 301-324.

Suri, T. (2017). Mobile money. Annual Review of Economics, 9, 497-520.

UNSGSA (United Nations Secretary-General's Special Advocate) (2018). Igniting SDG progress through digital financial inclusion. https://sustainabledevelopment.un.org/content/documents/2655SDG_Compendium_Dig ital_Financial_Inclusion_September_2018.pdf. 
Figure 1: Financial inclusion around the world

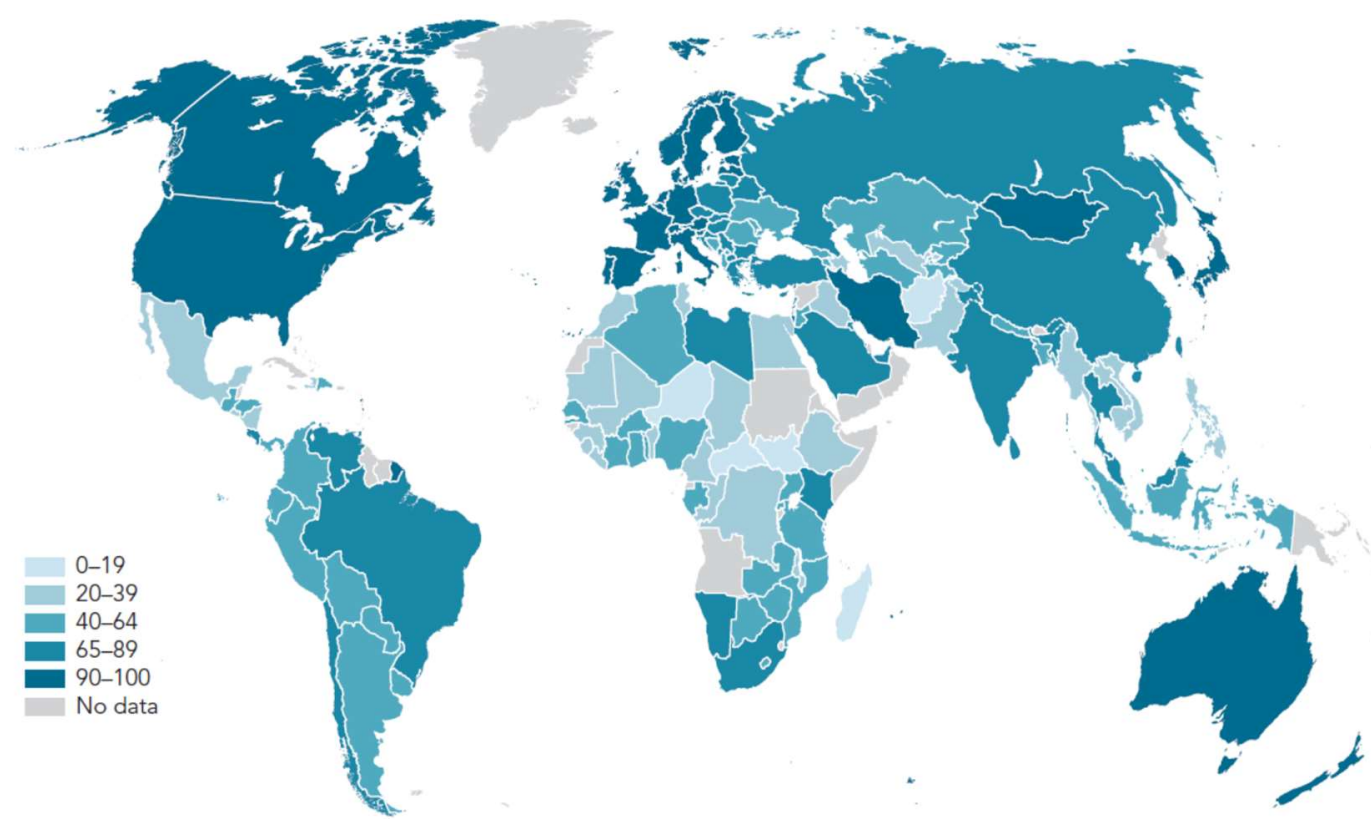

Source: Global Findex database 2017. Taken from 2017 Findex Report "The Global Findex Database 2017: Measuring Financial Inclusion and the Fintech Revolution"

Notes: The figure shows the proportion of adults in each country that have a bank account. Darker color represent a high proportion. 
Figure 2, Panel A:

Bank Account Ownership (\% with Account) by

Country Income Group

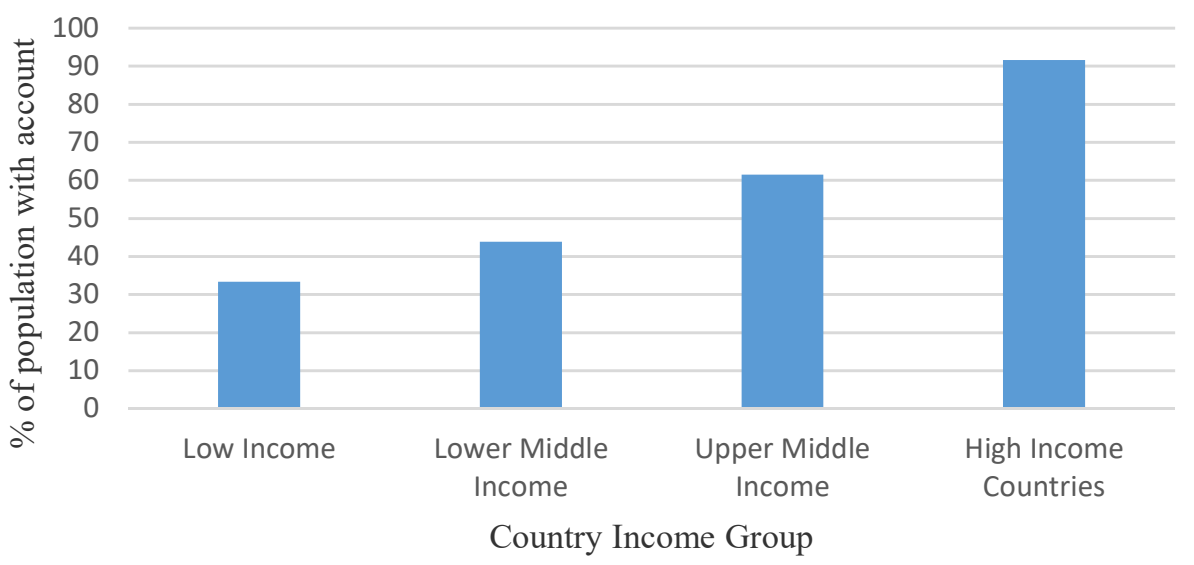

Notes: The figures shows the proportion of adults 15 years of older with a bank account by country income groups.

Source: Global Findex Data and authors own calculations

\section{Panel B:}

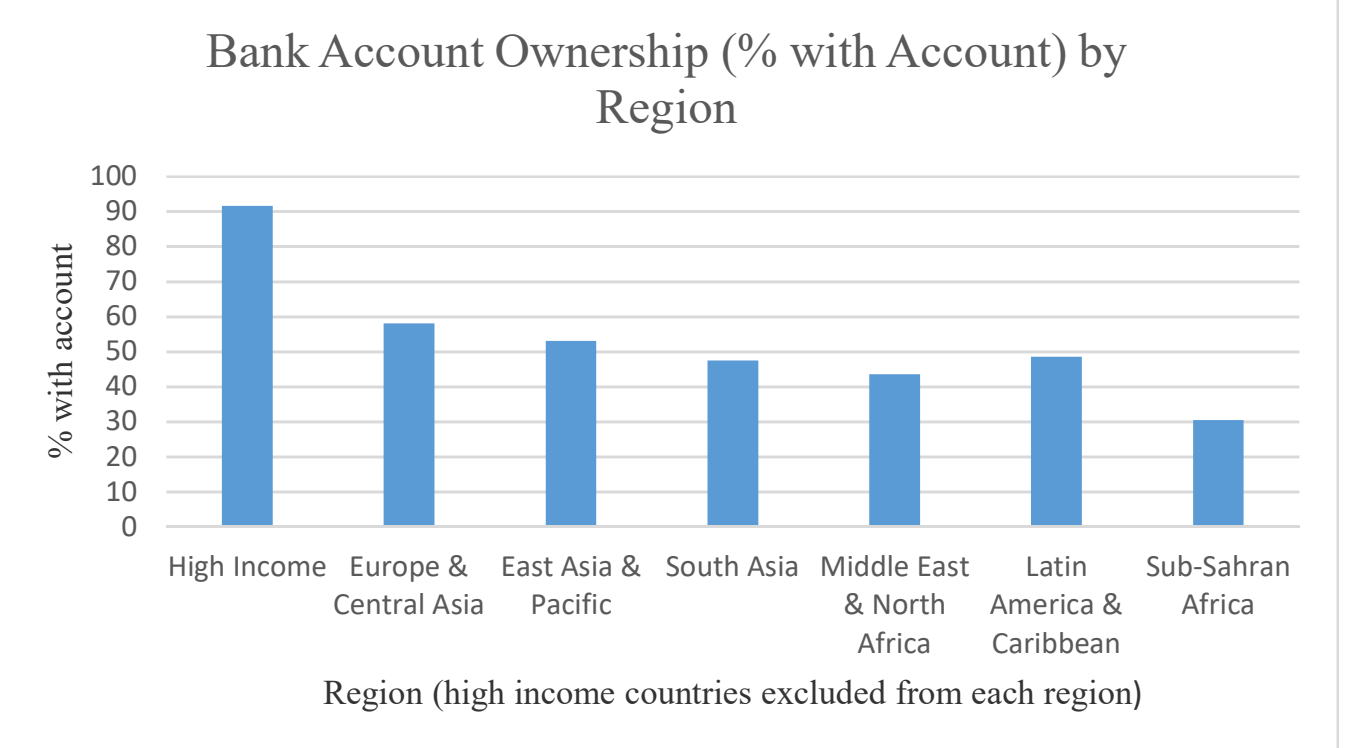

Notes: This figure shows the proportion of adults above 15 that have a bank account by region. All regions exclude high income countries.

Source: Global Findex Database and authors calculations. 
Figure 3:

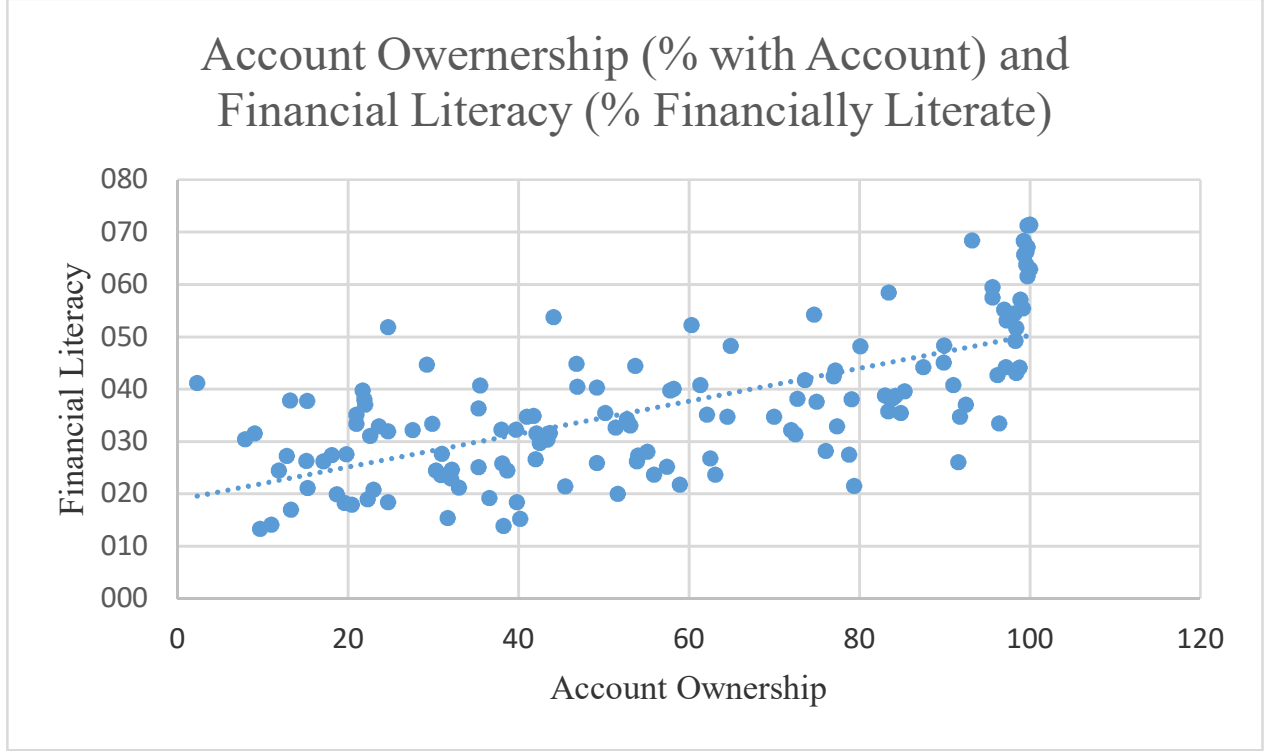

Notes: The figure shows a plot between the proportion of adults in a country that has a savings account and the proportion of people in a country that can answer questions on three out of four concepts correctly for 143 countries.

Source: Global Findex Data, S\&P Global Financial Literacy Data and authors calculations. 